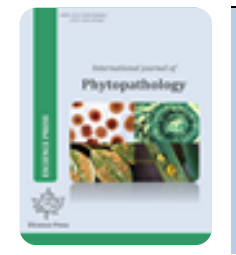

Available Online at EScience Press

International Journal of Phytopathology

ISSN: 2312-9344 (Online), 2313-1241 (Print)

https://esciencepress.net/journals/phytopath

\title{
DETECTION OF MAJOR SOIL-BORNE VIRUSES AND ASSESSMENT OF VIRUS-VECTOR ASSOCIATION IN POTATO GROWING AREAS OF NORTH-WESTERN PAKISTAN (KHYBER PAKHTUNKHWA) AND AZAD JAMMU AND KASHMIR
}

\author{
aNayla Haneef, a Muhammad Arif, bMuhammad Tariq-Khan \\ ${ }^{a}$ Department of Plant Pathology, Faculty of Crop Protection Sciences, The University of Agriculture, Peshawar, Pakistan. \\ ${ }^{b}$ Department of Plant Pathology, Faculty of Agriculture, University of Poonch Rawalakot, Azad Jammu and Kashmir, Pakistan.
}

\section{ART ICLE IN F O}

\section{Article history}

Received: June 11, 2021

Revised: August 19, 2021

Accepted: August 28, 2021

\section{Keywords}

Potato

Incidence

PMTV

TRV

Spongospora subterranean

Trichodorus

Paratrichodorus

Association

\section{A B S T R A C T}

Soil-borne potato viruses are an increasing economic threat to crop yield in the future. Potato mop-top virus (PMTV) and Tobacco rattle virus (TRV) and their vector association in field infection in North-western region of Pakistan and Azad Jammu and Kashmir were surveyed in this study. Incidence and distribution of these soilborne viruses were estimated by field sample collection from Malakand and Hazara divisions of KPK and selected areas of Azad Kashmir. PMTV incidence was 22\% in Malakand (highest of $40 \%$ in Swat II and Swat V), 24\% in Hazara (highest 50\% in Galliyat), and 23\% from selected areas of Azad Jammu and Kashmir (AJK) (Highest with $40 \%$ in Rawalakot and Trarkhal). TRV incidence was 49\% in AJK (100\% highest field incidence in Khaigala Rawalakot), 53\% in Malakand division (80\% highest field incidence in Swat II), and 24\% in Hazara division (70\% highest field incidence in Abbottabad and Mansehra districts). PMTV, TRV vectors are Spongospora subterranea and Trichodorus, Paratrichodorus spp. were found distributed in all surveyed areas. Eighty percent (80\%) fields were found infested with $S$. subterranean, while Trichodorus and Paratrichodorus were found in $64 \%$ in Malakand. In Hazara, $84 \%$ of surveyed fields were found infested with S. subterranea while $65 \%$ were found to be infested with Trichodorus, Paratrichodorus. In AJK $S$. subterranea was found distributed in $79 \%$ of fields. A significant relationship (P value $=0.000$ ) between viruses (PMTV and TRV) and their respective vectors were detected in proportionate. The corresponding $\mathrm{R}^{2}(0.70$ and 0.82$)$ indicates positive relation between viruses and their vectors. Positive Pearson correlation was found among incidence and severity of virus infection (PMTV and TRV) and vectors ( $S$. subterranea; Trichodorus minor, Paratrichodorus), indicating increased disease severity with vector presence and activity. The study will be a tool in vector virus management to economical potato harvest.

\section{Corresponding Author: Muhammad Tariq-Khan}

Email: muhammadtariq@upr.edu.pk

(c) The Author(s) 2021.

\section{INTRODUCTION}

Potato (Solanum tuberosum) is an important crop that belongs to the family Solanaceae, genus Solanum. It is cultivated in temperate, tropical, and subtropical regions (Hawkes, 1990; Stevenson et al., 2001). 
Potential biotic threats include fungi, nematodes, bacteria, viruses, viroids, phytoplasmas, and insect pests to potato crop. Viruses are among important pathogens that are transferred via diverse vectors (Jeffries et al., 2005; Valkonen, 2007). Plant-parasitic nematodes are found infesting vegetable crops in Azad Jammu and Kashmir (Tariq-Khan et al., 2017; Tariq-Khan et al., 2020c; Tariq-Khan et al., 2020a; Tariq-Khan et al., 2020b) including endo-parasitic and ecto-parasitic root-knot nematodes. Potato mop-top virus (PMTV) and Tobacco rattle virus (TRV) are transmitted by Spongospora subterranea and various species of soil-borne plant pathogenic nematode groups Trichodorus and Paratrichodorus. PMTV is type species of genus Pomovirus; family Virgaviridae (King et al., 2011) and is responsible for spreading disease in potato tubers (Harrison and Reavy, 2002). Spongospora subterranea incites powdery scab disease of potato, has been reported as PMTV vector (Jones and Harrison, 1969; Hims, 1975; Arif et al., 1995). It acts not only as an obligate parasite but vector of PMTV in potato crop. Resting fungal spores can survive for many years in the soil without a suitable plant host (Jones and Harrison, 1969; Harrison and Jones, 1970; Arif et al., 1995; Merz, 1995; Campbell, 1996). Major symptoms are brown circles on tuber surface and arcs in flesh of susceptible potato cultivars with reduced aesthetic value (Kurppa, 1989; Sandgren, 1995; Sandgren et al., 2002). The temperature in the range of $12-20^{\circ} \mathrm{C}$ is conducive to infect potato tubers and provides the base for host selection (Carnegie et al., 2010).

TRV is a Tobravirus and is considered important soilborne potato virus (Robinson and Harrison, 1989), resulting in corky ring-spot in potato. TRV has rigid rod-shaped particles with two types; M type, and NM type, based on their genomic makeup (Nicolaisen et al., 1999). TRV causes corky ring-spot in potato. The primary symptoms of this disease are internal discoloration which sometimes leads to arcs or circles in potato tuber flesh. The infested tissues have corky texture and symptoms visible on tuber surface and ringspot inside tuber flesh (Harrison, 1970) reducing aesthetic value. Stubby-root nematodes are soil-borne vector of TRV are polyphagous, and feed on from the roots of plants as migratory ecto-parasites. Initially, root becomes stunted then growth of roots is reduced due to direct damage by trichodorid nematodes
(Harrison and Robinson, 1986).

Soil-borne viruses are important for seed and storage potato production in Pakistan. Little work has been done to detect and identify soil-borne potato viruses (Rehman, 2013; Arif et al., 2014). Major soil-borne viruses and their association with vectors are still missing to be explained for potato crop. This study explains the incidence, distribution, and virus vector association of soil-borne viruses (PMTV and TRV) from potato crop cultivated from various locations of the North-western region of Pakistan and Azad Jammu and Kashmir.

\section{MATERIAL AND METHODS}

Collection of potato tubers and soil samples for detection of Pathogens and their vectors

Potato tubers and soil samples were collected from 24 locations of Malakand and Hazara divisions, Northwestern Khyber Pakistan, and from selected potato growing areas of Azad Jammu and Kashmir during March 2015. The fields were sampled in zigzag pattern, and soil samples were taken from 20-30 cm (Whitehead and Hooper, 1970). One kg composite soil sample from one location was collected, packed in polyethylene bags with some addition of freshwater for nematodes survival, and taken to the Nematology lab at Department of Plant Pathology, The University of Agriculture, Peshawar, and stored at $4{ }^{\circ} \mathrm{C}$. The sampled potato tubers from 24 locations were kept at room temperature.

\section{Assessment of PMTV and TRV infection in potato tubers based on symptoms}

Potato tubers were assessed for the external symptoms of PMTV and TRV and cut into two halves, and data of internal symptoms were recorded by comparing scale 0 4 (Table 1) (Robinson and Harrison, 1989). The percent incidence of PMTV and TRV and their vectors ( $S$. subterranea and Trichodorus, Paratrichodorus) was determined by using formula given below (Allen, 1983).

$$
\text { Incidence }=\frac{\text { Infested Tubers }}{\text { Total Number of tested Tubers }} \times 100
$$

\section{Detection and Assessment of PMTV and TRV infection in Potato tubers}

Potato mop-top virus has been detected and identified based of external and internal symptoms on tubers and by DAS-ELISA. DAS-ELISA was performed by coating 
with conjugate antibodies (Adgen Phyto-diagnostics, UK). The tests were performed in polystyrene micro- plates (NUNC, Immunoplate II, Thermal scientific, MA, USA) (Clark and Adams, 1977; Arif et al., 2014).

Table 1: Scale designed, modified, and used for the assessment of severity of Potato mop-top virus and Tobacco rattle virus in potato tubers.

\begin{tabular}{clcc}
\hline Scale & Description & $\begin{array}{c}\text { Mean } \mathrm{A}_{405 \mathrm{~nm}} \text { value } \\
\text { (PMTV) }\end{array}$ & $\begin{array}{c}\text { Mean } \mathrm{A}_{405 \mathrm{~nm}} \text { value } \\
\text { (TRV) }\end{array}$ \\
\hline 0 & No reaction apparently healthy & 0.140 & 0.140 \\
1 & Positive (hardly visible reaction) & 0.350 & 0.389 \\
2 & Positive (quite visible reaction) & 0.745 & 0.750 \\
3 & Positive (strong reaction) & 1.245 & 1.250 \\
4 & Positive (very strong intense reaction) & 1.750 & 1.750 \\
\hline
\end{tabular}

Assessment of powdery scab infection in potato tubers

Tuber samples were visually examined for the powdery scab infection using an assessment key (Iftikhar et al., 2007; Nakayama et al., 2007).

\section{Extraction and identification of nematode vector from soil}

The nematodes were extracted using the Modified Baermann technique (Whitehead and Hemming, 1965) from $100 \mathrm{~g}$ fine soil by placing it on tissue paper on coarse sieve in a tray filled with fresh water. Tray will be kept at room temperature for maximum downward movement of nematode fauna for 24-36 h for maximum nematode harvest. The soil in sieves was removed and discarded. Water suspension containing nematodes was transferred to sterilized glass beakers and allowed to settle for 3-4 hours. Extra water was removed by siphoning, and collected settled nematodes were put into counting dish for population estimation. Nematode suspensions were passed through $32 \mu \mathrm{m}$, and $25 \mu \mathrm{m}$ mesh size sieves for maximum number of nematodes (Trichodorus and Paratrichodorus). Nematodes extracted were counted under stereoscopic microscope (6X magnification), and their population density was determined using method (Whitehead and Hooper, 1970).

\section{Detection of TRV in nematode vector}

To confirm viruliferous nematode, ten nematodes per sample were picked using dropper and put into an eppendorf tubes with $2 \mathrm{ml}$ virus-specific extraction buffer. The nematodes were centrifuged at 8,000$10,000 \mathrm{rpm}$ for $5-10 \mathrm{~min}$, then re-suspended the pellet into $0.5 \mathrm{ml}$ of extraction buffer followed by frozen at $80{ }^{\circ} \mathrm{C}$ for $30 \mathrm{~min}$, then thawed on ice and used for
ELISA detection (Arif et al., 2014).

Assessment of the association between soil-borne viruses and their vectors

Association of soil-borne viruses (PMTV and TRV) and their vectors $S$. subterranean; Trichodorus; Paratrichodorus was assessed with the Jaccard Similarity Index (J) as described by Montero-Astúa et al. (2008). Linear regression was performed to test the significance of association of the virus (PMTV and TRV) with $S$. subterranean, Trichodorus and Paratrichodorus) respectively. The relationship between incidence and severity was computed by Pearson correlations using Statistics 8.1 package (Öfversten, 1995).

\section{RESULTS}

Symptom based identification and DAS-ELISA confirmation of PMTV (Potato Mop Top Virus)

PMTV exhibited necrotic rings on tuber surface and necrotic lesions as brown arc in tuber flesh. PMTV infected potato tubers of susceptible cultivars planted in the field were found with cracks and distortion. The average incidence of PMTV in Malakand based on external and internal symptoms on tuber was $24 \%$ and $20 \%$, respectively, while in Hazara, it was estimated as $23 \%$ and $24.4 \%$, respectively (Table 2 ) and average estimated incidence in Azad Jammu and Kashmir was $20 \%$ in external and $26 \%$. The results were further confirmed by the detection of PMTV in potato tubers using DAS-ELISA. The $\mathrm{A}_{405} \mathrm{~nm}$ value of positive samples was relatively lighter than the three times mean values of healthy control. PMTV was detected in 12 out of 50 tuber samples tested from 
Malakand division, while 11 out of 45 were from Hazara division. PMTV was also detected in 5 out of 25 tubers from Azad Kashmir (Table 3).

\section{Symptom-based identification and DAS-ELISA confirmation of TRV}

Potato tuber exhibited symptoms like raised necrotic rings, corky ring spots on tuber surface, and multiple necrotic flecks/lines in tuber flesh as internal symptoms with 53 and 54\% tubers, respectively. In
Hazara division the average incidence of TRV was $52 \%$ and $46 \%$, while highest (70\%) and lowest (30\%) incidence was observed in Abbottabad and Mansehera districts. In Azad Kashmir, 20\% incidence was observed externally on tubers and 78\% internally (Table 2). TRV confirmed with DAS-ELISA in potato tubers of almost all surveyed areas, the incidence was highest $44 \%$ in Malakand division, followed by $42 \%$ to Hazara division and 36\% from Azad Jammu and Kashmir (Table 4).

Table 2: Detection of major soil-borne viruses of potato in Northwest of Pakistan on the basis of external and internal symptoms.

\begin{tabular}{|c|c|c|c|c|c|c|}
\hline \multirow{3}{*}{ Division/Region } & \multirow{3}{*}{ District } & \multirow{3}{*}{ Location } & \multicolumn{4}{|c|}{ Detection of soil-borne viruses } \\
\hline & & & \multicolumn{2}{|c|}{ PMTV (\%) } & \multicolumn{2}{|c|}{ TRV (\%) } \\
\hline & & & $\begin{array}{c}\text { External sym } \\
\text { on tuber }^{1}\end{array}$ & $\begin{array}{c}\text { Internal sym } \\
\text { on tuber }{ }^{2}\end{array}$ & $\begin{array}{c}\text { External sym } \\
\text { on } \text { tuber }^{3}\end{array}$ & $\begin{array}{c}\text { Internal sym } \\
\text { on tuber }{ }^{4}\end{array}$ \\
\hline \multirow{10}{*}{ Malakand } & \multirow{4}{*}{ Shangla } & Shangla I & 10 & 10 & 40 & 60 \\
\hline & & Shangla II & 10 & 10 & 50 & 60 \\
\hline & & Shangla III & 30 & 20 & 60 & 60 \\
\hline & & Shangla IV & 30 & 20 & 60 & 60 \\
\hline & \multirow{6}{*}{ Swat } & Swat I & 10 & 10 & 50 & 50 \\
\hline & & Swat II & 40 & 40 & 80 & 60 \\
\hline & & Swat III & 30 & 20 & 60 & 60 \\
\hline & & Swat IV & 20 & 10 & 30 & 50 \\
\hline & & Swat V & 40 & 40 & 50 & 40 \\
\hline & & Swat VI & 20 & 20 & 50 & 40 \\
\hline Average incidence & & & 24 & 20 & 53 & 54 \\
\hline \multirow{9}{*}{ Hazara } & \multirow{4}{*}{ Abbottabad } & Galliyat & 50 & 40 & 60 & 60 \\
\hline & & Namlimaira & 20 & 10 & 60 & 60 \\
\hline & & Sajikot & 40 & 40 & 60 & 60 \\
\hline & & Mangal & 10 & 10 & 70 & 70 \\
\hline & \multirow{5}{*}{ Manshera } & Shinkiari & 20 & 30 & 30 & 40 \\
\hline & & Parhana & 10 & 20 & 40 & 30 \\
\hline & & Khaki & 40 & 40 & 70 & 60 \\
\hline & & Baffa & 10 & 20 & 30 & 30 \\
\hline & & Bajna & 10 & 10 & 50 & 40 \\
\hline Average incidence & & & 23 & 24.4 & 52 & 46 \\
\hline \multirow{5}{*}{ Azad Kashmir } & \multirow{4}{*}{ Poonch } & Rawalakot & 40 & 40 & 30 & 60 \\
\hline & & Khaigala & 0 & 10 & 20 & 100 \\
\hline & & Chottagala & 10 & 20 & 10 & 70 \\
\hline & & Banjonsa & 10 & 20 & 30 & 80 \\
\hline & Sudhnoti & Trarkhal & 40 & 40 & 10 & 80 \\
\hline Average incidence & & & 20 & 26 & 20 & 78 \\
\hline
\end{tabular}

Disease rating scale is given in Table 1; sym: Symptoms 
Assessment of association of PMTV with $S$. subterranea using Jaccard Similarity Index (JSI)

Significant association of PMTV and S. subterranea was computed in field conditions (Table 5). PMTV and S. subterranean computed association $12.2 \%$ found in Malakand division from 120 samples, highest $20 \%$ in district Swat and lowest $8.3 \%$ in district Shangla. In
S. Hazara division, overall computed association was $4.6 \%$ from 285 samples, highest 9.1\% in Khaki, and no association was found in Parhana, district Manshera. In Azad Jammu and Kashmir JSI was 5.3\% from 117 samples, highest $22.2 \%$ in Trarkhal, and no association was detected in Banjonsa and Khaigala (Table 5).

Table 3: Incidence and severity of Potato mop-top virus and S. subterranea in selected areas of Northwest of Pakistan.

\begin{tabular}{|c|c|c|c|c|c|c|}
\hline \multirow{2}{*}{ Division/Region } & \multirow{2}{*}{ District } & \multirow{2}{*}{ Location } & \multicolumn{2}{|c|}{ Incidence $^{1}$} & \multicolumn{2}{|c|}{ Severity $^{2}$} \\
\hline & & & PMTV (\%) & S. subterranea (\%) & PMTV & S. subterranean \\
\hline \multirow{10}{*}{ Malakand } & \multirow{4}{*}{ Shangla } & Shangla I & 20 & 71 & 3 & 2 \\
\hline & & Shangla II & 20 & 65 & 2 & 2 \\
\hline & & Shangla III & 20 & 80 & 2 & 2 \\
\hline & & Shangla IV & 20 & 82 & 3 & 2 \\
\hline & \multirow{6}{*}{ Swat } & Swat I & 20 & 77 & 2 & 2.5 \\
\hline & & Swat II & 40 & 92 & 2 & 2 \\
\hline & & Swat III & 20 & 87 & 3 & 1.5 \\
\hline & & Swat IV & 20 & 71 & 2 & 2.5 \\
\hline & & Swat V & 40 & 100 & 2 & 3.5 \\
\hline & & Swat VI & 20 & 80 & 2 & 2.5 \\
\hline Average incidence & & & 24 & 80 & & \\
\hline \multirow{9}{*}{ Hazara } & \multirow{4}{*}{ Abbottabad } & Galliyat & 40 & 100 & 2 & 3 \\
\hline & & Namlimaira & 20 & 77 & 3 & 2.5 \\
\hline & & Sajikot & 40 & 96 & 2.5 & 3 \\
\hline & & Mangal & 20 & 80 & 2 & 4 \\
\hline & \multirow{5}{*}{ Manshera } & Shinkiari & 20 & 80 & 2 & 3.5 \\
\hline & & Parhana & 0 & 71 & 0 & 2.5 \\
\hline & & Khaki & 40 & 100 & 2.5 & 3.5 \\
\hline & & Baffa & 20 & 77 & 3 & 4 \\
\hline & & Bajna & 20 & 72 & 3 & 3 \\
\hline Average incidence & & & 24.4 & 84 & & \\
\hline \multirow{5}{*}{ Azad Kashmir } & \multirow{4}{*}{ Poonch } & Rawalakot & 40 & 100 & 1.5 & 3.5 \\
\hline & & Khaigala & 0 & 50 & 0 & 3 \\
\hline & & Chottagala & 20 & 66 & 3 & 3 \\
\hline & & Banjonsa & 0 & 78 & 0 & 3.5 \\
\hline & Sudhnoti & Trarkhal & 40 & 100 & 1.5 & 3 \\
\hline Average incidence & & & 20 & 79 & & \\
\hline
\end{tabular}

Disease Severity Scales:

$0=0.140$ (No reaction apparently healthy)

$1=0.350$ (Positive hardly visible reaction)

$2=0.745$ (Positive quite visible reaction)

$3=1.245$ (Positive strong reaction)

$4=1.750$ (Positive very strong intense reaction)

1. Potato mop top virus (PMTV)

2. S. subterranea $0=$ No infection; $1=$ Less than $1 \% ; 2=1-10 \% ; 3=11-20 \% ; 4=21-50 \%$; and $5=51 \%$ and more area infested respectively 
Table 4: Incidence and severity of Tobacco rattle virus and vector nematode in selected areas of Northwest of Pakistan.

\begin{tabular}{|c|c|c|c|c|c|c|}
\hline \multirow[b]{2}{*}{ Division/Region } & \multirow[b]{2}{*}{ District } & \multirow[b]{2}{*}{ Location } & \multicolumn{2}{|c|}{ Incidence $^{1}$} & \multicolumn{2}{|c|}{ Severity $^{2}$} \\
\hline & & & TRV (\%) & $\begin{array}{l}\text { Nematode } \\
\text { vector }(\%)\end{array}$ & TRV & $\begin{array}{c}\text { Nematode } \\
\text { Vector }\end{array}$ \\
\hline \multirow{10}{*}{ Malakand } & \multirow{4}{*}{ Shangla } & Shangla I & 40 & 60 & 3 & 2 \\
\hline & & Shangla II & 40 & 65 & 3 & 2 \\
\hline & & Shangla III & 60 & 70 & 2 & - \\
\hline & & Shangla IV & 60 & 70 & 2 & 2 \\
\hline & \multirow{6}{*}{ Swat } & Swat I & 40 & 62 & 2 & -3 \\
\hline & & Swat II & 60 & 75 & 1 & 2 \\
\hline & & Swat III & 40 & 64 & 3 & - \\
\hline & & Swat IV & 20 & 50 & 2 & - \\
\hline & & Swat V & 40 & 68 & 3 & 3 \\
\hline & & Swat VI & 40 & 60 & 2 & - \\
\hline \multicolumn{2}{|l|}{ Average incidence } & & 44 & 64 & & \\
\hline \multirow{9}{*}{ Hazara } & \multirow{4}{*}{ Abbottabad } & Galliyat & 60 & 72 & 1 & - \\
\hline & & Namlimaira & 40 & 67 & 2 & 3 \\
\hline & & Sajikot & 40 & 64 & 2 & 2 \\
\hline & & Mangal & 60 & 78 & 3 & - \\
\hline & \multirow{5}{*}{ Manshera } & Shinkiari & 20 & 55 & 2 & 3 \\
\hline & & Parhana & 40 & 58 & 2 & - \\
\hline & & Khaki & 60 & 70 & 2 & 2 \\
\hline & & Baffa & 20 & 54 & 3 & 3 \\
\hline & & Bajna & 40 & 65 & 2 & 2 \\
\hline Average incidence & & & 42 & 65 & & \\
\hline \multirow{5}{*}{ Azad Kashmir } & \multirow{4}{*}{ Poonch } & Rawalakot & 40 & & 2 & $* 4$ \\
\hline & & Khaigala & 40 & & 3 & $*$ \\
\hline & & Chottagala & 40 & & 3 & $*$ \\
\hline & & Banjonsa & 60 & & 1 & $*$ \\
\hline & Sudhnoti & Trarkhal & 0 & & 0 & $*$ \\
\hline \multicolumn{3}{|l|}{ Average incidence } & 36 & & & \\
\hline
\end{tabular}

Severity Scale of TRV and vector nematode is

$0=0.140$ (No reaction apparently healthy);

$1=0.389$ (Positive hardly visible reaction);

$2=0.750$ (Positive quite visible reaction);

$3=1.250$ (Positive strong reaction);

$4=1.750$ (Positive very strong intense reaction).

Locations where vector severity were not identified * Locations where vector severity were not tested

Assessment of association of TRV and Trichodorus, Paratrichodorus spp. using JSI

Positive interaction between TRV and its nematode vector was found (Table 6), with highest association $30 \%$ each in two districts of Malakand and 33.3\% in
Namlimaira (Abbottabad) in Hazara. In comparison, the lowest association (9.1\%) was observed in Swat IV Malakand, $16.6 \%$ in Parhana and Baffa Hazara. The JSI value for 100 samples from Malakand was $21.8 \%$ and 90 samples from Hazara were 22.6\% (Table 6). 
Table 5: Association of PMTV and S. subterranea using Jaccard Similarity Index.

\begin{tabular}{|c|c|c|c|c|c|c|c|}
\hline \multirow{2}{*}{ Division } & \multirow{2}{*}{ District } & \multirow{2}{*}{ Location } & \multirow{2}{*}{ No. of samples } & \multicolumn{3}{|c|}{ PMTV/S. subterranea ${ }^{2}$} & \multirow{2}{*}{ Jaccard Index } \\
\hline & & & & $a+/+$ & $b+/-$ & $c-/+$ & \\
\hline \multirow{10}{*}{$\begin{array}{l}\text { Malakand } \\
(\mathrm{KPK})\end{array}$} & \multirow{4}{*}{ Shangla } & Shangla I & 14 & 1 & 1 & 9 & 9.1 \\
\hline & & Shangla II & 14 & 1 & 0 & 8 & 11.1 \\
\hline & & Shangla III & 15 & 1 & 0 & 11 & 8.3 \\
\hline & & Shangla IV & 11 & 1 & 0 & 8 & 11.1 \\
\hline & \multirow{6}{*}{ Swat } & Swat I & 13 & 1 & 0 & 9 & 10.0 \\
\hline & & Swat II & 12 & 2 & 1 & 9 & 16.6 \\
\hline & & Swat III & 8 & 1 & 0 & 6 & 14.3 \\
\hline & & Swat IV & 14 & 1 & 0 & 9 & 10.0 \\
\hline & & Swat V & 9 & 2 & 1 & 7 & 20.0 \\
\hline & & Swat VI & 10 & 1 & 1 & 7 & 11.1 \\
\hline Total & & & 120 & 12 & 4 & 83 & 12.2 \\
\hline \multirow{9}{*}{$\begin{array}{l}\text { Hazara } \\
(\mathrm{KPK})\end{array}$} & \multirow{4}{*}{ Abbottabad } & Galliyat & 30 & 2 & 1 & 28 & 6.5 \\
\hline & & Namlimaira & 31 & 1 & 1 & 23 & 4.0 \\
\hline & & Sajikot & 28 & 2 & 1 & 25 & 7.2 \\
\hline & & Mangal & 25 & 1 & 0 & 19 & 5.0 \\
\hline & \multirow{5}{*}{ Manshera } & Shinkiari & 56 & 1 & 0 & 44 & 2.2 \\
\hline & & Parhana & 28 & 0 & 0 & 20 & 0.0 \\
\hline & & Khaki & 21 & 2 & 1 & 19 & 9.1 \\
\hline & & Baffa & 30 & 1 & 0 & 22 & 4.4 \\
\hline & & Bajna & 36 & 1 & 0 & 25 & 3.8 \\
\hline Total & & & 285 & 11 & 4 & 225 & 4.6 \\
\hline \multirow{5}{*}{$\begin{array}{c}\text { Azad } \\
\text { Jammu and } \\
\text { Kashmir } \\
\text { (AJK) }\end{array}$} & \multirow{4}{*}{ Poonch } & Rawalakot & 40 & 2 & 1 & 38 & 4.8 \\
\hline & & Khaigala & 20 & 0 & 0 & 10 & 0.0 \\
\hline & & Chottagala & 35 & 1 & 0 & 22 & 4.4 \\
\hline & & Banjonsa & 14 & 0 & 0 & 11 & 0.0 \\
\hline & Sudhnoti & Trarkhal & 8 & 2 & 1 & 6 & 22.2 \\
\hline Total & & & 117 & 5 & 2 & 87 & 5.3 \\
\hline
\end{tabular}

${ }^{1}$ Data of virus incidence was based on ELISA detection.

2 Values showing positive $(+)$ and negative $(-)$ test results for Potato mop top virus

$$
\text { Jaccard Index }(\text { S. subterranea })=\frac{a}{(a+b+c)} \times 100
$$

Where $\mathrm{a}=$ the number of samples where both the virus and vector present. $\mathrm{b}=$ the number of samples where the virus present but the vector was absent. $\mathrm{c}=$ the number of samples where the vector present but the virus was absent.

Assessment of association between PMTV and $S$. subterranea using regression analysis

The association between PMTV incidence and $S$. subterranea incidence has been determined, which is highly significant $(\mathrm{P}$-value $=0.000)$ with 0.83 co-efficient of determination 0.83 . It is determined that $1 \%$ increase in incidence of $S$. subterranea in field increase PMTV incidence $0.97 \%$ (Figure 1). The relationship between PMTV and $S$. subterranea incidence on internal symptoms in potato tubers revealed positive relationship with $0.73 \mathrm{R}^{2}$ (Figure 2) value. Further, when the incidence of vector under field conditions increases by $1 \%$, the incidence of PMTV increases by $0.79 \%$. The regression analysis for the vector and PMTV based on ELISA (Figure 3) shows $\mathrm{R}^{2}$ value as 0.70 . The relationship between incidence of PMTV and vector were found to be statistically significant at (P-value= 0.000). Under field conditions, when the population of $S$. subterranea increases by $1 \%$ it increases $0.80 \%$ PMTV incidence. 
Table 6: Association of TRV and nematode vector using Jaccard Similarity Index.

\begin{tabular}{|c|c|c|c|c|c|c|c|}
\hline \multirow{2}{*}{$\begin{array}{l}\text { Division/ } \\
\text { Region }\end{array}$} & \multirow{2}{*}{ District } & \multirow{2}{*}{ Location } & \multirow{2}{*}{ No. of samples } & \multicolumn{3}{|c|}{ TRV/ Nematode vector ${ }^{2}$} & \multirow{2}{*}{ Jaccard Index } \\
\hline & & & & $\mathrm{a} \quad+/+$ & $\mathrm{b}+/-$ & c $\quad-/+$ & \\
\hline \multirow{10}{*}{ Malakand } & \multirow{4}{*}{ Shangla } & Shangla I & 10 & 2 & 0 & 6 & 25.0 \\
\hline & & Shangla II & 10 & 2 & 0 & 6 & 25.0 \\
\hline & & Shangla III & 10 & 3 & 1 & 6 & 30.0 \\
\hline & & Shangla IV & 10 & 3 & 1 & 6 & 30.0 \\
\hline & \multirow{6}{*}{ Swat } & Swat I & 10 & 2 & 1 & 10 & 15.4 \\
\hline & & Swat II & 10 & 3 & 1 & 6 & 30.0 \\
\hline & & Swat III & 10 & 2 & 0 & 10 & 16.6 \\
\hline & & Swat IV & 10 & 1 & 0 & 10 & 9.1 \\
\hline & & Swat V & 10 & 2 & 1 & 4 & 28.6 \\
\hline & & Swat VI & 10 & 2 & 0 & 10 & 16.6 \\
\hline \multirow[t]{5}{*}{ Total } & & & 100 & 22 & 5 & 74 & 21.8 \\
\hline & & Galliyat & 10 & 3 & 1 & 10 & 21.4 \\
\hline & & Namlimaira & 10 & 2 & 0 & 4 & 33.3 \\
\hline & Abbottabad & Sajikot & 10 & 2 & 0 & 6 & 25.0 \\
\hline & & Mangal & 10 & 3 & 1 & 10 & 21.4 \\
\hline \multirow[t]{5}{*}{ Hazara } & & Shinkiari & 10 & 1 & 0 & 4 & 20.0 \\
\hline & & Parhana & 10 & 2 & 0 & 10 & 16.6 \\
\hline & & Khaki & 10 & 3 & 1 & 6 & 30.0 \\
\hline & Manshera & Baffa & 10 & 1 & 1 & 4 & 16.6 \\
\hline & & Bajna & 10 & 2 & 1 & 6 & 22.2 \\
\hline Total & & & 90 & 19 & 5 & 60 & 22.6 \\
\hline
\end{tabular}

${ }^{1}$ Data of virus incidence was based on ELISA detection.

2 Values showing positive (+) and negative (-) test results for Potato mop top virus

Where;

$$
\text { Jaccard Index }(\text { S. subterranea })=\frac{a}{(a+b+c)} \times 100
$$

$\mathrm{a}=$ the number of samples where both the virus and vector present.

$\mathrm{b}=$ the number of samples where the virus present but the vector was absent.

$\mathrm{c}=$ the number of samples where the vector present but the virus was absent.

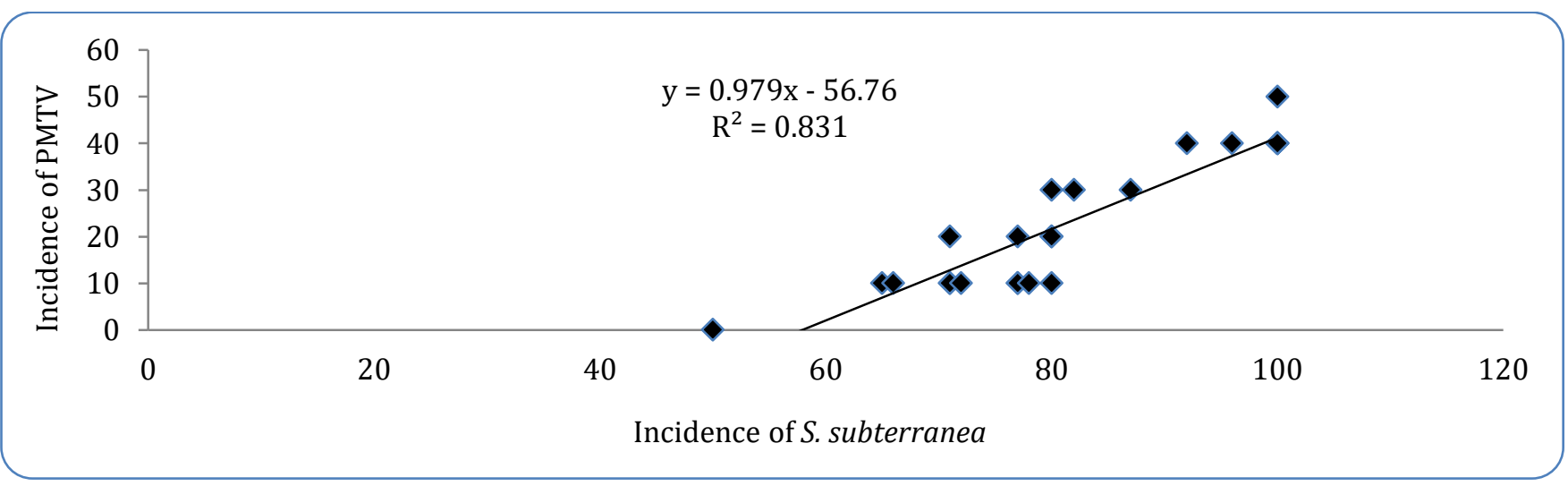

Figure 1: Regression analysis of PMTV on S. subterranea on the basis of external symptoms. 


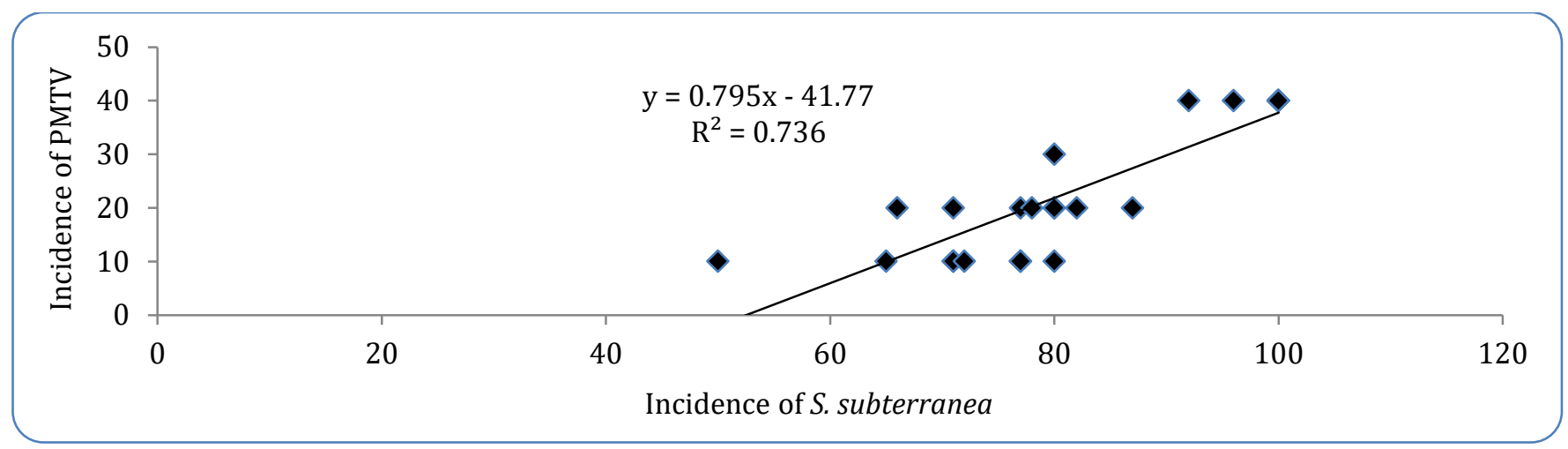

Figure 2: Regression analysis of PMTV on S. subterranea on the basis of internal symptoms.

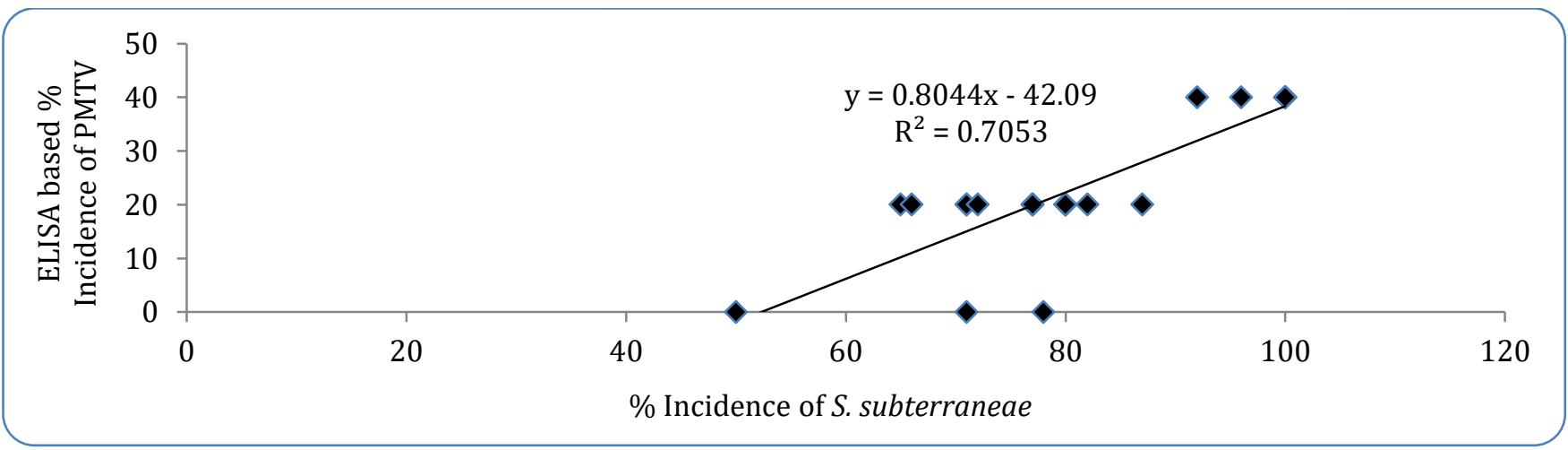

Figure 3: Regression analysis of PMTV on S. subterranea based on ELISA detection.

\section{Assessment of association between TRV and its vector}

Positive linear regression relationships were computed between TRV and its vector. The $1.76 \%$ increase in TRV incidence result of $1 \%$ population increase of Trichodorus minor, Paratrichodorus during the growing season (Pvalue $=0.000)$ a significant association $\left(\mathrm{R}^{2} 0.83\right)$ between vector and TRV (Figure 4). The regression analysis between TRV incidence and nematode vector based on internal symptoms on potato tubers is shown in (Figure $5)$. The value of $R^{2}=0.45$, which is lower than the threshold value $\left(R^{2}=0.5\right)$. Such interaction is said to be statistically significant (P-value=0.000). ELISA-based regression analysis on incidence of TRV and incidence of its vector show positive relationship (P-value $=0.000$ ). With $1 \%$ increase in incidence of nematode vector in the field conditions, the incidence of TRV is also increased by 1.71\% (Figure 6).

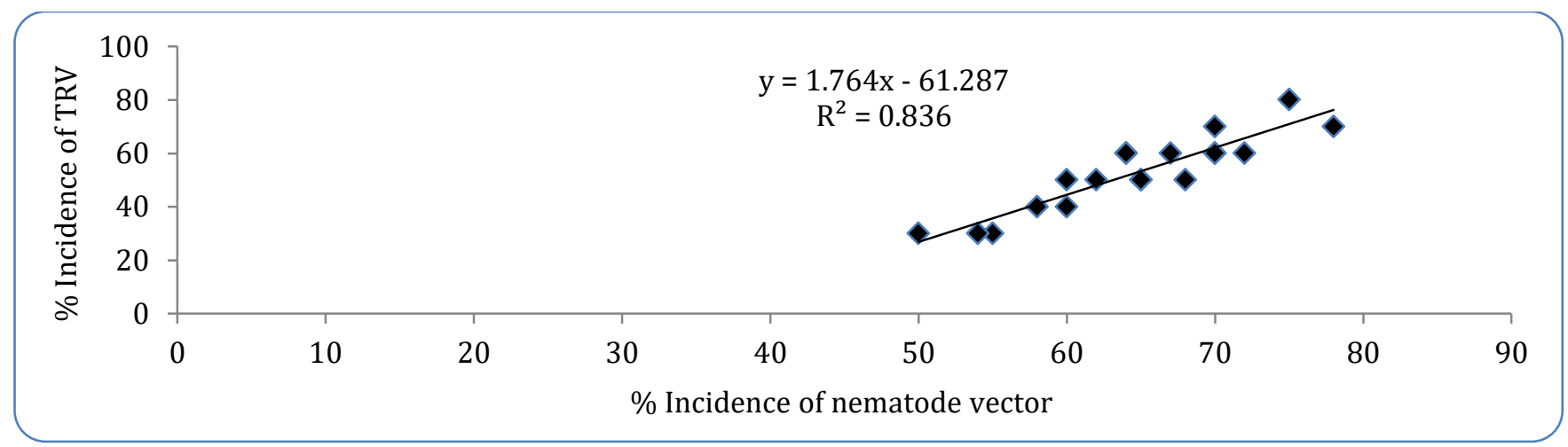

Figure 4: Regression analysis of TRV on nematode vector based on external symptoms. 


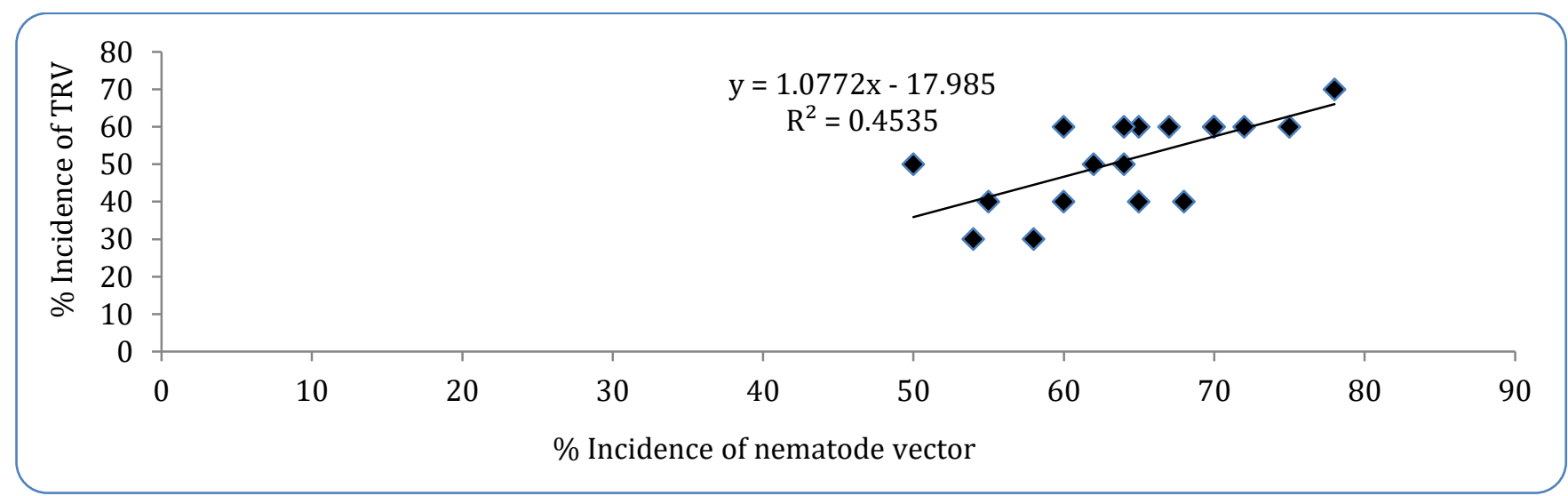

Figure 5: Regression analysis of TRV on nematode vector based on internal symptoms.

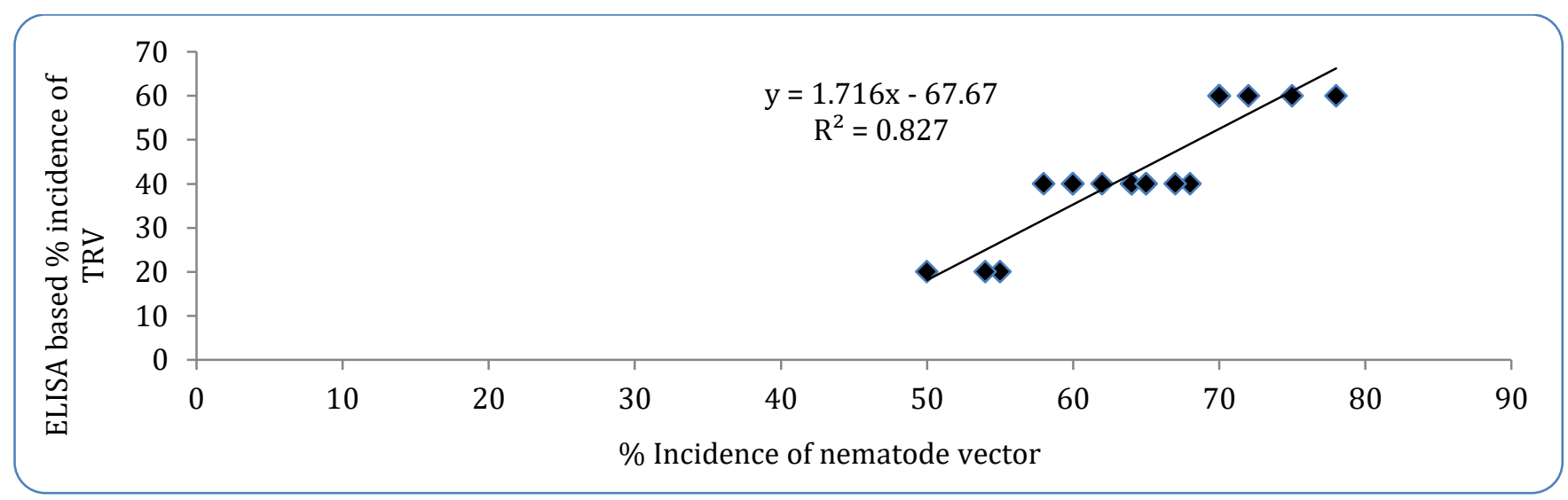

Figure 6: Regression analysis of TRV on nematode vector based on ELISA detection.

Interaction estimation of PMTV severity and $S$. subterranean

The correlation between incidence of PMTV and disease severity was statistically significant as P-value is 0.037 (Table 7). The bivariate Pearson correlation between incidence of PMTV and S. subterranea incidence was found associated with disease severity under field conditions are summarized (Table7). S. subterranea positively enhanced the disease severity $(r=0.20)$, but it is not much influenced.

\section{Impact of nematode vector on infection of TRV}

Incidence of nematode vector and TRV disease severity were also found to be positive correlated $(\mathrm{r}=0.18)$ though statistically insignificant, an indication of poor positive correlation. Slight positive association was determined $(\mathrm{r}=0.053)$ between nematode vector presence of TRV which was detected by ELISA method and was non-significant (P-value=0.81) (Table 8).
Correlation analysis estimates revealed severity of TRV and nematode vector increase with the increase of its incidence but inconsistent way.

\section{DISCUSSION}

Soil-borne viruses (PMTV and TRV) and their vectors were prevalent in Malakand and Hazara divisions of Khyber Pakhtunkhwa and selected locations in Azad Kashmir. The incidence of both viruses and their vectors was found higher in Malakand and Hazara division than Azad Kashmir. The variability in the incidence amongst the localities and in individual field may be due to the soil type, climate, and altitude difference. The average incidence of $S$. subterranea was recorded quite higher than the incidence of PMTV in Malakand, Hazara and selected areas of Azad Kashmir, respectively. The higher incidence of the fungal virus vector ( $S$. subterranea) in this region is already reported (Ahmad et al., 1996; Iftikhar et al., 2007). 
Table 7: Correlation between PMTV and S. subterranea incidence and disease severity.

\begin{tabular}{lccc}
\hline & Pearson correlation (r) & P-value & No. of observations \\
\hline PMTV (incidence and severity) & 0.427 & 0.037 & 24 \\
Spongospora subterranea (incidence and severity) & 0.206 & 0.333 & 24 \\
\hline
\end{tabular}

*. Correlation is significant at the 0.05 level.

Table 8: Correlation between TRV and nematode vector incidence and disease severity.

\begin{tabular}{lccc}
\hline Pathogen & Pearson correlation (r) & P-value & No. of observations \\
\hline TRV (incidence and severity) & 0.053 & 0.87 & 24 \\
Nematode vector (incidence and severity) & 0.184 & 0.452 & 19 \\
\hline
\end{tabular}

High humidity and moisture level in field facilitate the germination of zoospores in acquisition and transmission of PMTV in field with the help of its fungal vectors (Teakle, 1988). It increases virus infested seeds and increased field contaminations with local seed multiplications for a long time in the same fields. 3-4 crops per year further enhance incidence without disease-free certified potato seeds. Both temperature and humidity affect the association between the virus and the vector, in PMTV and S. subterranea or TRV and its nematode vector. The temperature and humidity are changing with altitude in the North-western seed potato producing regions, and same trend were found around the world (Delfosse et al., 2002). The other reason for the highest incidence of both virus and the vector must be the multiplication of local seeds for a long time. The flow of virus-free certified seed is limited in the system and import of germplasm without proper quarantine regulations. Growing 3-4 potato crops in a year enhances the virus-vector inoculum in the region.

The interaction and association of viruses (PMTV; TRV) and their vectors was calculated by Jaccard Similarity Index and linear regression (Montero-Astúa et al., 2008). Regression analysis showed significant relationship (Pvalue $=0.000$ ) between viruses (PMTV; TRV) and their vectors. The corresponding $\mathrm{R}^{2}$ indicates positive association between viruses and their vector. Statistically, significant regression means that with the increase in the incidence of the vectors in the field the incidence of viruses also increases. Pearson correlation was applied to determine the relationship between the incidence and severity of viruses (PMTV and TRV) and also for their vectors ( $S$. subterranea and Trichodorus minor, Paratrichodorus spp.). The relevant Pearson correlation indicates positive correlation indicated an increase in incidence of viruses and their vectors, also increasing the disease severity (Chaudhry, 1988).

In general, the present study indicated that where higher incidence of the soil-borne vectors (both plasmodiophorid and nematodes) was found, the incidence of the soil-borne viruses (PMTV and TRV) were high. However, magnitude of associations between virus and vectors was low as pervious findings (Nielsen and Nicolaisen, 2003; Tenorio et al., 2006; MonteroAstúa et al., 2008). As in case of PMTV most of the potato cultivars are susceptible to both the virus and the vector (Arif et al., 2013; Iftikhar et al., 2007). The Association of TRV and its nematode vector is still needed to be explored. Stringent need for quarantine implementation and surveillance to avoid the disease (De Boer, 2000; Merz et al., 2005) and disease-free seed for crop multiplication are imperative to avoid the diseases. The study helps in understanding relationship status of Plasmodiophorid, nematode-transmitted viruses and their vectors and nature of association. Exploration regarding candidate genes against PMTV and TRC cannot be ignored for long. Natural resistance genes in potatoes are not yet documented against PMTV in potato cultivars worldwide (Santala et al., 2010; Valkonen, 2007). Evaluation of potato germplasm from various parts of the world is needed to be identified for durable plant disease management.

\section{CONCLUSION}

PMTV and TRV are found in the potato crop grown in KPK AJK, and a positive correlation exists between disease incidences of virus vectors. Vectors were prevalent in the North-western region of Pakistan with significant associations between viruses and their vectors with low magnitude. A positive correlation was found between incidence and severity of soil-borne viruses and their vectors. 


\section{ACKNOWLEDGMENTS}

This work was partially funded by Higher Education Commission, Islamabad, under National Research Program for Universities (NRPU) through Grant No. 20$1182 / R$ \& D/08.

\section{REFERENCES}

Ahmad, J., M. H. N. Choudhery, S. Salah-ud-Din and M. A. Ali. 1996. Stability for grain yield in wheat. Pakistan Journal of Botany, 28: 61-66.

Allen, R. N. 1983. Spread of banana bunchy top and other plant virus diseases in time and space. In: R. T. Plumb and J. M. Thresh (eds.), Plant virus Epidemiology. The spread and control of insectborne viruses.

Arif, M., M. Ali, A. Rehman and M. Fahim. 2013. Occurrence of potato mop-top virus in Northwest of Pakistan. European Journal of Plant Pathology, 137: 787-96.

Arif, M., M. Ali, A. Rehman and M. Fahim. 2014. Detection of potato mop-top virus in soils and potato tubers using bait-plant bioassay, ELISA and RT-PCR. Journal of Virological Methods, 195: 221-27.

Arif, M., L. Torrance and B. Reavy. 1995. Acquisition and transmission of potato mop-to furovirus by a culture of Spongospora subterranea f.sp. subterranea derived from a single cystosorus. Annals of Applied Biology, 126: 493-503.

Campbell, R. N. 1996. Fungal transmission of plant viruses. Annual review of phytopathology, 34: 87 108.

Carnegie, S. F., T. Davey and G. S. Saddler. 2010. Effect of temperature on the transmission of Potato mop-top virusfrom seed tuber and by its vector, Spongospora subterranea. Plant Pathology, 59: 22-30.

Chaudhry, S. M. 1988. Introduction to Statistical Theory. Ihmi Kitab Khana: Lahore, Pakistan.

Clark, M. F. and A. N. Adams. 1977. Characteristics of the microplate method of enzyme-Linked immunosorbent assay for the detection of plant viruses. Journal of General Virology, 34: 475-83.

De Boer, R. F. 2000. Summary of the session on recognising the components of an integrated control approach to powdery scab and the Potato Mop Top Virus. Proceedings of the first European powdery scab workshop, Aberdeen, Scotland.

Delfosse, P., A. S. Reddy, K. Thirumala Devi, A. Legrève, J. Risopoulos, D. Doucet, P. Shoba Devi, H. Maraite and D. V. R. Reddy. 2002. Dynamics of Polymyxa graminis and Indian peanut clump virus (IPCV) infection on various monocotyledonous crops and groundnut during the rainy season. Plant Pathology, 51: 546-60.

Harrison, B. D. 1970. Tobacco Rattle Virus. CMI/ AAB "Description of plant viruses." No.120 Commonwealth Mycological Institute/Association of Applied Biologists. Kew, Survey. England.

Harrison, B. D. and R. A. C. Jones. 1970. Host range and some properties of potato mop-top virus. Annals of Applied Biology, 65: 393-402.

Harrison, B. D. and B. Reavy. 2002. Potato Mop-Top Virus. CMI/ AAB "Description of plant viruses." No. $398 \quad$ Commonwealth Mycological Institute/Association of Applied Biologists. Kew, Survey. England.

Harrison, B. D. and D. J. Robinson. 1986. Tobraviruses. In: M. H. V. Van Regenmortel and H. FraenkelConrat (eds.), The Plant Viruses. Plenum Press. New York, USA.

Hawkes, J. G. 1990. The potato: Evolution, biodiversity and genetic resources. American Potato Journal, 67: 733-35.

Hims, M. J. 1975. Spongospora subterranea f.sp. subterranea. (Descriptions of Fungi and Bacteria) IMI Descriptions of Fungi and Bacteria. CAB International.

Iftikhar, S., A. Rattu, S. Asad and K. Burney. 2007. Susceptibility of potato cultivars to Spongospora subterranea under field conditions. Pakistan Journal of Botany, 39: 1329-33.

Jeffries, C., H. Barker and S. M. P. Khurana. 2005. Potato viruses (and viroids) and their management. In, Potato production, improvement and post-harvest management. New York, USA. The Haworth's Food Products Press.

Jones, R. A. C. and B. D. Harrison. 1969. The behaviour of potato mop-top virus in soil, and evidence for its transmission by Spongospora subterranea (Wallr.) lagerh. Annals of Applied Biology, 63: 1-17.

King, A. M. Q., E. Lefkowitz, M. J. Adams and E. B. Carstens. 2011. Virus Taxonomy: Ninth report of the International Committee on Taxonomy of Viruses. Elsevier: London, UK.

Kurppa, A. 1989. The distribution and incidence of Potato Mop-Top Virus in Finland as determined in 1987 and on the variation of disease symptoms in 
infected potatoes. Annal of Agriculture Fennland, 28: 285-295.

Merz, U. 1995. PMTV-like particles inside resting spores of Spongospora subterranea. Journal of Phytopathology, 143: 731-33.

Merz, U., P. Y. Jaquiéry, A. Keiser, T. H. Oberhaensli and J. A. Walsh. 2005. Powdery scab-tools for an integrated control approach. Proceedings of the 16th Triennial Conference of the European Association of Potato Research, Bilbao, Spain.

Montero-Astúa, M., V. Vasquéz, W. W. Turechek, U. Merz and C. Rivera. 2008. Incidence, distribution, and association of Spongospora subterranea and Potato mop-top virus in Costa Rica. Plant disease, 92: 1171-1176.

Nakayama, T., M. Horita and T. Shimanuki. 2007. Spongospora subterranea soil contamination and its relationship to severity of powdery scab on potatoes. Journal of General Plant Pathology, 73: 229-234.

Nicolaisen, M., Z. Bösze and S. L. Nielsen. 1999. Detection of tobacco rattle virus in potato tubers using a simple RT-PCR procedure. Potato Research, 42: 173-179.

Nielsen, S. L. and M. Nicolaisen. 2003. Identification of two nucleotide sequence sub-groups within Potato mop-top virus. Archives of virology, 148: 381-388.

Öfversten, J. 1995. Estimation in mixed models via layer triangular transformation. Computational Statistics and Data Analysis, 20: 657-667.

Rehman, S. U. 2013. Study of important soil-borne viruses in major potato growing areas of Hazara and Malakand divisions, The University of Agriculture Peshawar.

Robinson, D. J. and D. B. Harrison. 1989. Tobacco rattle virus. CMI/AAB. Descriptions of Plant Viruses No. $346 \quad$ Commonwealth Mycological Institute/Association of Applied Biologists. Kew, Survey. England.

Sandgren, M. 1995. Potato mop-top virus (PMTV): Distribution in Sweden, development of symptoms during storage and cultivar trials in field and glasshouse. Potato Research, 38: 379-89.

Sandgren, M., R. L. Plaisted, K. N. Watanabe, S. Olsson and J. P. T. Valkonen. 2002. Evaluation of some North and South American potato breeding lines for resistance to Potato mop-top virus in Sweden.
American Journal of Potato Research, 79: 205-10. Santala, J., O. Samuilova, A. Hannukkala, S. Latvala, H. Kortemaa, U. Beuch, A. Kvarnheden, P. Persson, K. Topp, K. Ørstad, C. Spetz, S. L. Nielsen, H. G. Kirk, M. Budziszewska, P. Wieczorek, A. ObrępalskaStęplowska, H. Pospieszny, A. Kryszczuk, J. Sztangret-Wiśniewska, Z. Yin, M. Chrzanowska, E. Zimnoch-Guzowska, E. Jackeviciene, L. Taluntytè, N. Pūpola, J. Mihailova, I. Lielmane, L. Järvekülg, K. Kotkas, E. Rogozina, A. Sozonov, I. Tikhonovich, P. Horn, I. Broer, S. Kuusiene, J. Staniulis, J. G. Uth, G. Adam and J. P. T. Valkonen. 2010. Detection, distribution and control of Potato mop-top virus, a soil-borne virus, in northern Europe. Annals of Applied Biology, 157: 163-178.

Stevenson, W., R. R. Loria, G. D. Franc and D. P. Weingartner. 2001. Compendium of Potato Diseases. American Phytopathological Society: USA.

Tariq-Khan, M., S. Z. A. Gardazi, A. D. A. Khan, M. Ilyas and I. Ahmad. 2020a. Virulence and Distribution Trends of Root-Knot Nematode (RKN) Fauna on Summer Vegetables in District Bagh, Azad Jammu and Kashmir (Pakistan). Pakistan Journal of Nematology, 38: 139-48.

Tariq-Khan, M., A. D. A. Khan, M. Saeed, S. Z. A. Gardazi, B. Mehmood and R. Ahmed. 2020b. Distribution and virulence of root-knot nematodes on summer vegetables in Sudhnuti district of Azad Jammu and Kashmir. Pakistan Journal of Phytopathology, 32: 257-264.

Tariq-Khan, M., T. Mukhtar, A. Munir, J. Hallmann and H. Heuer. 2020c. Comprehensive report on the prevalence of root-knot nematodes in the Poonch division of Azad Jammu and Kashmir, Pakistan. Journal of Phytopathology, 168 322-336.

Tariq-Khan, M., A. Munir, T. Mukhtar, J. Hallmann and H. Heuer. 2017. Distribution of root-knot nematode species and their virulence on vegetables in northern temperate agro-ecosystems of the Pakistani-administered territories of Azad Jammu and Kashmir. Journal of Plant Diseases and Protection, 124: 201-12.

Teakle, D. S. 1988. The effect of environmental factors on fungus-transmitted viruses and their vectors. In, Developments in Applied Biology II. Viruses with Fungal Vectors. Association of Applied Biologist. Wellebourne, England.

Tenorio, J., Y. Franco, C. Chuquillanqui, R. A. Owens and 
L. F. Salazar. 2006. Reaction of potato varieties to Potato mop-top virus infection in the andes. American Journal of Potato Research, 83: 423-31.

Valkonen, J. P. T. 2007. Viruses: Economical losses and biotechnological potential Potato Biology and Biotechnology. Elsevier. pp. 619-641.

Whitehead, A. G. and J. R. Hemming. 1965. A comparison of some quantitative methods of extracting small vermiform nematodes from soil. Annals of Applied Biology, 55: 25-38.

Whitehead, A. G. and D. J. Hooper. 1970. Needle nematodes (Longidorus spp.) and stubby-root nematodes (Trichodorus spp.) harmful to sugar beet and other field crops in England. Annals of Applied Biology, 65: 339-350.

\section{CONFLICT OF INTEREST}

The authors have not declared any conflict of interests.

\section{AUTHORS CONTRIBUTIONS}

All the authors contributed equally to this work.

Publisher's note: EScience Press remains neutral with regard to jurisdictional claims in published maps and institutional affiliations.

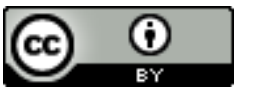

Open Access This article is licensed under a Creative Commons Attribution 4.0 International License, which permits use, sharing, adaptation, distribution and reproduction in any medium or format, as long as you give appropriate credit to the original author(s) and the source, provide a link to the Creative Commons license and indicate if changes were made. The images or other third-party material in this article are included in the article's Creative Commons license, unless indicated otherwise in a credit line to the material. If material is not included in the article's Creative Commons license and your intended use is not permitted by statutory regulation or exceeds the permitted use, you will need to obtain permission directly from the copyright holder. To view a copy of this license, visit http://creativecommons.org/licenses/by/4.0/. 